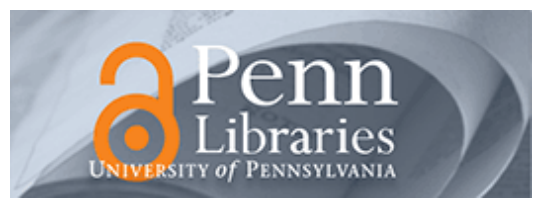

University of Pennsylvania

ScholarlyCommons

March 2007

\title{
Student Organizations as Venues for Black Identity Expression and Development among African American Male Student Leaders
}

Shaun R. Harper

University of Pennsylvania, sharper1@gse.upenn.edu

Stephen John Quaye

Pennsylvania State University

Follow this and additional works at: https://repository.upenn.edu/gse_pubs

\section{Recommended Citation}

Harper, S. R., \& Quaye, S. J. (2007). Student Organizations as Venues for Black Identity Expression and Development among African American Male Student Leaders. Retrieved from https://repository.upenn.edu/gse_pubs/166

Copyright (c) 2007 The John Hopkins University Press. This article first appeared in Journal of Student College Development, Volume 48, Issue 2, March 2007, pages 127-144.

Note: At the time of publication, the author, Shaun R. Harper, was affiliated with the Pennsylvania State University. Currently, he is a faculty member in the Graduate School of Education at the University of Pennsylvania.

This paper is posted at ScholarlyCommons. https://repository.upenn.edu/gse_pubs/166

For more information, please contact repository@pobox.upenn.edu. 


\title{
Student Organizations as Venues for Black Identity Expression and Development among African American Male Student Leaders
}

\author{
Abstract \\ Ways in which membership in student organizations, both predominantly Black and mainstream, provide \\ space for Black identity expression and development were explored in this study. Based on individual \\ interviews conducted with African American male student leaders at six predominantly White universities, \\ findings reveal a nexus between Black identity status, the selection of venues for out-of-class \\ engagement, and the use of student organizations as platforms for racial uplift and the advocacy of \\ racial/ethnic minority student interests. Moreover, the acquisition of cross-cultural communication skills, \\ the development of care for other disenfranchised groups, and the pursuit of social justice via leadership \\ and student organization membership were reported by the participants and are connected to racial \\ identity development theories in this article.
}

\section{Keywords}

African American male college student, African American race identity, African American leadership

\section{Comments}

Copyright $@ 2007$ The John Hopkins University Press. This article first appeared in Journal of Student College Development, Volume 48, Issue 2, March 2007, pages 127-144.

Note: At the time of publication, the author, Shaun R. Harper, was affiliated with the Pennsylvania State University. Currently, he is a faculty member in the Graduate School of Education at the University of Pennsylvania. 


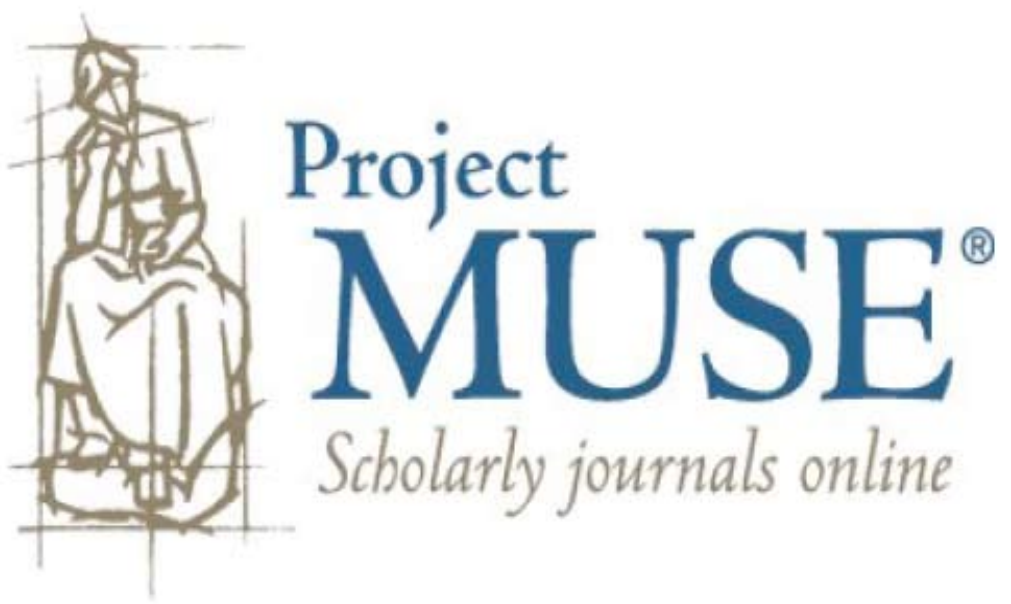




\section{Student Organizations as Venues for Black Identity Expression and Development among African American Male Student Leaders}

Shaun R. Harper Stephen John Quaye

Ways in which membership in student organizations, both predominantly Black and mainstream, provide space for Black identity expression and development were explored in this study. Based on individual interviews conducted with African American male student leaders at six predominantly White universities, findings reveal a nexus between Black identity status, the selection of venues for out-of-class engagement, and the use of student organizations as platforms for racial uplift and the advocacy of raciallethnic minority student interests. Moreover, the acquisition of cross-cultural communication skills, the development of care for other disenfranchised groups, and the pursuit of social justice via leadership and student organization membership were reported by the participants and are connected to racial identity development theories in this article.

Although the ongoing exploration of their needs and experiences is warranted, considerable attention has been previously devoted to studying African American college students. Sedlacek (1987) offered a comprehensive synthesis of 20 years of research on African American collegians wherein he elaborated on the racism, isolation, sociocultural challenges, and academic obstacles that many of these students face at predominantly White institutions (PWIs). One contemporary issue is the retention crisis concerning African American male undergraduates. More than two-thirds of those who start college never graduate (National Center for Education Statistics [NCES], 2005), which is the worst college completion rate among both sexes and all racial/ethnic groups in higher education (Harper, 2006a). Although the causes of student attrition are multifaceted and complex (Braxton, 2000; Tinto, 2005), Evans, Forney, and GuidoDiBrito (1998) asserted that identity conflict is largely responsible for a significant number of early departures from the college campus. Specifically regarding African American men, Cuyjet (2006) and Harper (2004) attributed a portion of low persistence rates to identity challenges.

Since the introduction of Cross's (1971) model of Black identity development, the importance of racial identity as a contributing factor to psychosocial wellness among African Americans has been well-documented in the social science and education literature. Despite this, the intersection between race and gender among African American college men remains grossly understudied (Harper, 2004; HowardHamilton, 1997; Taylor \& Howard-Hamilton, 1995). Using data from the College Student Experiences Questionnaire, Flowers (2004) examined the effects of in-class and out-ofclass involvement on African American student development_racial identity development was not among the outcomes considered in his study. If student affairs educators and faculty are to better comprehend and address the

Shaun R. Harper is an Assistant Professor and Research Associate and Stephen John Quaye is a doctoral candidate and Research Assistant, both in the Center for the Study of Higher Education at The Pennsylvania State University. 
dilemma of African American male attrition and outcomes disparities, understanding how persisters and academically successful undergraduate men translate their racial identity statuses into educationally purposeful engagement would be a useful endeavor.

Scholars have recently called attention to the inappropriateness of treating African American students as a monolithic group in higher education research and practice (Brown, 1994; Cuyjet, 2006; Fries-Britt, 1998, 2002; Fries-Britt \& Turner, 2001; Harper, 2004, 2005, 2006b; Torres, Howard-Hamilton, \& Cooper, 2003; White, 1998). They noted several important within-group variations in the experiences of African American undergraduate students and called for a more intensive and disaggregated study of different subpopulations within the race. Many researchers have examined the development of racial and other dimensions of students' identities, yet few have focused specifically on African American men.

Taylor and Howard-Hamilton's (1995) study appears to be the first that exclusively considered the racial identities of African American male undergraduates. Quantitative in design, the study measured racial identity attitudes, with no discussion or exploration of how these attitudes were formed or the vehicles through which men with strong attitudes actually expressed their Black identities. Though not disaggregated by sex, Mitchell and Dell's (1992) analysis of survey responses from 55 African American students revealed a link between racial identity attitudes and student organization participation. Accordingly, those who were more engaged outside of the classroom, especially in predominantly Black or culturally based groups, expressed stronger Black identity attitudes, which is also consistent with Taylor and Howard-Hamilton's findings.

The purpose of the present study is to introduce a shift in the study of racial identity development and expression - from attitudinal and quantitative to behavioral and qualitative. The venues through which African American male student leaders develop and express their Black identities are considered in this article. In light of previous findings regarding the nexus between student organization membership and racial identity attitudes, emphasis here is placed on the ways in which African American men use student organizations as platforms for the expression of their Blackness. Mitchell and Dell (1992) argued that additional inquiry is needed on the factors that compel African American student engagement in campus organizations and activities. Guiffrida's (2003) study on undergraduate membership in predominantly Black student organizations offered some insight, but three issues make the provision of additional research necessary: (a) findings were not disaggregated by sex, thus specific dimensions of African American men's experiences remain unknown; (b) the emphasis was on social integration, not identity development and expression; and (c) African American student engagement in predominantly White and mainstream student organizations was overlooked. Hence, the present study also seeks to fill what continues to be a void in the literature on Black identity and African American student engagement in various types of clubs, organizations, and campus activities.

\section{LITERATURE REVIEW \\ Black Identity Development}

Helms (1990) defined racial identity as "a sense of group or collective identity based on one's perception that he or she shares a common racial heritage with a particular racial group" (p. 3). Many foundational studies on Black identity development suggested a movement along various stages in which individuals 
progress from a lack of awareness and understanding about the implications of their race to an in-depth exploration process leading to a more secure sense of racial self that comfortably crosses cultural boundaries (Cross, 1971, 1991, 1995; Cross \& Vandiver, 2001; Howard-Hamilton, 2000; Thompson \& Carter, 1997; Vandiver, Fhagen-Smith, Cokley, Cross, \& Worrell, 2001; Vandiver, Cross, Worrell, \& Fhagen-Smith, 2002; Worrell, Cross, \& Vandiver, 2001). Psychological Nigrescence, or the process of "becoming Black," became an area of interest for some scholars during the social movements of the 1960s and 1970s. William Cross introduced a five-stage theoretical model in 1971 to explain Nigrescence, which he later reduced to the following four stages: Pre-Encounter, Encounter, Immersion-Emersion, and Internalization. Cross described Nigrescence as a "resocializing experience" in which a preexisting identity is transformed from non-Africentrism to Africentrism to multiculturalism.

In the Pre-Encounter stage, individuals exhibit a lack of interest in their race or the race of others and often embrace colorblindness and a race-neutral notion of humanity. During the Encounter stage, persons experience an incident or dissonance of some sort that awakens consciousness of their race, which in turn ignites feelings of anger, frustration, shame, or confusion. The third stage, Immersion-Emersion, is characterized by strong, positive feelings for the Black race (a pro-Black stance-"Everything in Black culture is positive and good") and disinterest in Whiteness (an anti-White stance- "I dislike every aspect of White culture; all White people are evil"). The exploration of ethnic history, the pursuit of knowledge about the oppression of Black people in America and elsewhere, and the collection of artifacts pertaining to Black culture are common for those at this stage.

Progression then leads to Internalization, the final stage in Cross's (1995) model, when African Americans begin to come to terms with their newfound sense of selves, accept the implications of their Black identities, and develop an inner peace and holistic understanding of what it means to be Black in a multicultural society. According to Evans et al. (1998), "relationships with White associates and people from other ethnic groups are renegotiated as internalization of the new Black identity takes hold” (p. 76). Persons at this stage also readily identify with, develop compassion for, and sometimes seek justice on behalf of others who experience social oppression and disenfranchisement (e.g., women, gay and lesbian persons, and members of religious minority groups). Here, the pursuit of equity, fairness, and social justice is not only deemed important for the Black race, but for other marginalized populations as well. Furthermore, Cross asserts that people at the Internalization stage can selectively subscribe to elements of both the Black and White cultures without forfeiting one for the other.

Vandiver et al. (2001) expanded Cross's (1995) model to include nine identity clusters. Worth mentioning here is the addition of the Multiculturalist Inclusive cluster to the Internalization stage, which pertains to a person's ability to bridge differences and understand the connections between multiple forms of oppression. Though Cross's model provides a backdrop for making sense of the complex developmental challenges facing African American male college students on predominantly White campuses, its stage-wise progression is limited in that it indicates a hierarchical process through which people must advance in order to reach the higher levels of racial identity development. Unlike Cross's theory, Robinson and HowardHamilton's (1994) Africentric Resistance Modality Model includes seven non-hierarchical principles in which an African 
American person can engage independently or simultaneously as a means of fostering a positive, secure sense of racial identity. Among the principles are Ujima, which stands for unity with other Black people that transcends gender, sexual orientation, and other socially constructed differences, as well as value placed on collective work in the quest to eradicate social inequities that disadvantage African Americans.

Cokley's (1999) distinction between racial awareness and racial ideology illuminates the necessity of not focusing exclusively on stagelike theories of racial identity development:

Racial awareness can be thought of as how often one appreciates, values, and is aware of one's racial and cultural heritage, whereas racial ideology has more to do with a set of beliefs one has about how members of one's racial group should act. (p. 237)

This difference is particularly important as it denotes the significance of taking into account individual recognitions of racial identity (racial awareness) as well as those of racial groups (racial ideology).

\section{Out-of-Class Engagement and Identity Development}

Previous studies have documented the beneficial effects of engagement in student organizations and out-of-class activities on identity development, retention, and other outcomes produced in college for African American students (Cokley, 2001; Evans et al., 1998; Flowers, 2004; Fries-Britt, 2000; Harper, 2004, 2006c; Harper, Byars, \& Jelke, 2005; Howard-Hamilton, 1997). Taylor and HowardHamilton's (1995) study examined the relationship between student engagement and racial identity attitudes among African American male students. Data collected from 117 participants at 10 PWIs suggest that higher levels of out-of-class engagement contribute to stronger racial identity attitudes. Specifically, highly involved students tended to be at the Immersion-Emersion and Internalization stages of Cross's (1995) model, whereas lessengaged participants reported higher levels of Pre-Encounter attitudes.

Though not specific to male college students, Mitchell and Dell (1992) also found strong correlations between Black identity, psychosocial development, and participation in campus organizations. They discovered a negative relationship between Pre-Encounter attitudes and participation in cultural activities, whereas Encounter, Immersion, and Internalization attitudes were positively correlated. Related findings emerged in Pope's (1998) study of the relationship between psychosocial development and the racial identities of African American college students.

Taylor and Howard-Hamilton (1995) contended that "many racial/ethnic minority students find themselves either subverting their identity and becoming involved in the mainstream campus or assimilating as they struggle to maintain a strong cultural connection" (p. 330). Similarly, White (1998) described the pressures that are often placed on African American students by their same-race peers to participate in Black student organizations; some participants in her study joined these organizations merely to keep their Black identities unquestioned. According to Harper (1975), many African American men at PWIs in the 1970s chose to develop their leadership skills within the African American community instead of in larger, mainstream campus organizations - which is a trend that reportedly holds true in contemporary times (Sutton \& Terrell, 1997). Because many of the clubs and student organizations in which African American men choose to participate are not seen as mainstream, administrators often fail to notice when some are actively involved on 
campus (Cokley, 2001; Harper, 2006c; Taylor \& Howard-Hamilton, 1995). Moreover, traditional conceptualizations of leadership that focus on the singular leader instead of collectivism, coupled with the accusations of "acting White" that are sometimes associated with involvement in mainstream campus organizations, explain, at least in part, why many African American men and other racial/ ethnic minority students find mainstream student organizations unappealing (Arminio et al., 2000; Fries-Britt, 2000; HowardHamilton, 1997; Taylor \& Howard-Hamilton, 1995).

King and Howard-Hamilton (2000) made clear the significance of constructing learning opportunities outside of the classroom that facilitate identity development among racial/ ethnic minority students. McEwen, Roper, Bryant, and Langa (1990) described nine dimensions necessary for including the unique developmental experiences of African Americans into previous developmentally based theories and models. Specifically, they stressed the importance of social interactions, collectivism, and group identification on the identity development of African American students. Of particular note, their ninth dimension, Developing Social Responsibility, indicates firsthand recognition of the social inequities that disadvantage African Americans in society and on their campuses, which compels some to become catalysts for social change. This sense of social activism is consistent with Mitchell and Dell's (1992) claim that various stages of Cross's (1995) Black identity model can stimulate African American students' participation in campus organizations.

Findings and implications from previous research cited in this section, coupled with the aforementioned gaps in the literature regarding Black identity expression (as opposed to attitudes) specifically among African American college men, led to the exploration of the following research questions: (a) What role does racial identity play in African American male student leaders' engagement in organizations and out-of-class activities on predominantly White campuses, (b) what factors influence African American men's selection of mainstream and culturally based student organizations, and (c) in what ways do student organizations support the development and expression of Black identities among African American male undergraduates?

\section{METHOD}

This article is based on findings from a qualitative study regarding the experiences of high-achieving African American undergraduate men who were actively involved and held leadership positions in multiple student organizations at PWIs. Data used here were extracted from a more comprehensive project. The phenomenological study sought to understand what it is like to be a highachieving African American male student leader at a large PWI and included questions regarding the participants' selection of student organizations, the impetus for their active involvement in out-of-class activities, and the experiences that influenced the development and expression of their racial identities. The phenomenology tradition in qualitative research focuses on understanding and describing the "lived experiences" of the participants involved in the study (Denzin \& Lincoln, 2000). A phenomenological account gets inside the common experience of a group of people and describes what the participants have experienced, how they have experienced it, and the meanings they make of their shared experience (Moustakas, 1994). Polkinghorne (1989) suggested that the researcher and readers of a phenomenological research study should be able to say, "I understand better what it is like for someone to experience that" 
(p. 46). This type of qualitative study usually provides full, detailed descriptions of the phenomenon under study (Miles \& Huberman, 1994).

\section{Sites}

This study was conducted at six large, public research universities in the Midwest: University of Illinois, Indiana University, University of Michigan, Michigan State University, The Ohio State University, and Purdue University. These six institutions are similar in terms of size, age, reputation, and selectivity. Collectively enrolling more than 189,000 undergraduates, these six institutions are all classified as Doctoral/Research Universities-Extensive by the Carnegie Foundation for the Advancement of Teaching (2000). On average, 6.3\% of the students at the institutions were African American during the time at which the data were collected, with African American undergraduate enrollments ranging from $3.1 \%$ to $8.8 \%$. The mean six-year graduation rate for African American male undergraduates at these institutions was $50.7 \%$, compared to $74.2 \%$ for White men and $58.8 \%$ for their African American female counterparts. Consistent with national trends (Harper, 2006a), African American men had the lowest graduation rates among both sexes and all racial/ethnic groups across the six universities. At the time of data collection, 33.8\% of the African American students at these universities were male.

\section{Sample}

Key administrators on the six campuses (i.e., deans, vice presidents, and directors of campus programs) were asked to identify highachieving African American male student leaders who had earned cumulative grade point averages above 3.0 on a 4.0 scale; established lengthy records of leadership and involvement in multiple campus organizations; earned the admiration of their peers (as determined by peer elections to campus leadership positions); developed meaningful relationships with faculty and high-ranking campus administrators; participated in enriching educational experiences (e.g., study abroad programs, internships, learning communities, and summer research programs); and earned numerous awards and honors for their college achievements. Using these criteria, 32 African American undergraduate men at the six universities were identified and selected for participation in this study.

The sample included four sophomores, 12 juniors, and 16 seniors, representing a wide variety of academic majors. The mean GPA for the sample was 3.32. All of the participants were between the ages of 18 and 22 and were single with no dependents. Twelve participants grew up in single-parent homes and the remaining 20 were from homes with two parents. Regarding the educational levels of their parents, the participants reported the following: both parents attended college $(n=9)$, one parent attended college $(n=10)$, and neither parent attended college $(n=13)$. Collectively, the 32 participants had been awarded more than $\$ 489,000$ in merit-based scholarships, awards, and prizes for their college achievements. The participants expressed high educational and career aspirations, with $72 \%$ indicating the intent to someday earn a doctoral degree. The remaining 28\% planned to pursue master's degrees, mostly MBAs from top business schools.

None of the participants in this study were college student-athletes. Nominators reported that these 32 high-achievers were the only African American male undergraduates on the six campuses who satisfied the previously noted criteria established for participation in this study.

\section{Data Collection Procedures}

Each of the 32 African American men was 
asked to participate in a 2- to 3-hour face-toface interview and at least two follow-up interviews via telephone. The lead researcher visited each campus at least once to conduct the first-round individual interviews; four campuses were visited twice. A semi-structured interview technique was used in the face-toface interview sessions, which simultaneously permitted data collection and authentic participant reflection (Holstein \& Gubrium, 1995). Although standard questions and interview protocol were used in the interviews, discussions often became conversational, thus allowing the participants to reflect on the experiences and relationships they deemed most significant. Full transcripts from all sessions were sent to each participant for confirmation within eight weeks following his interviews.

\section{Data Analysis}

Step-by-step techniques prescribed by Moustakas (1994) were used to analyze the data collected from interviews with the participants. We first bracketed our initial impressions and assumptions as we read each line of the participants' transcripts. The margins of the transcripts were marked with reflective comments regarding our own suppositions and preliminary judgments about the data. After bracketing, the transcripts were sorted and key phases were linearly arranged under tentative headings using the $\mathrm{NVivo}{ }^{\circledR}$ Qualitative Research Software Package. This process resulted in the identification of 36 invariant constituents (Moustakas), which were sub-themes that consistently held true for at least $84.4 \%$ of the sample. The invariant constituents were helpful in understanding the participants' shared experiences and were later clustered into thematic categories.

Before the categories were solidified, a textural summary (what the high-achiever experienced) and a structural summary (how he experienced the phenomenon of being an actively engaged student leader at a PWI) were written for each participant. Seven thematic categories were identified that captured the essence of the participants' shared experiences, two of which related directly to the development and expression of the participants' Black identities through student organizations on predominantly White university campuses. Only findings from those two themes are reported in this article.

\section{Trustworthiness and Quality Assurance}

Several steps were taken to ensure quality and trustworthiness in this study. Lincoln and Guba (1986) offered four measures for evaluating methodological rigor and accuracy in qualitative research: credibility, transferability, dependability, and confirmability. These four measures "replace the usual positivist criteria of internal and external validity, reliability, and objectivity" used to ensure quality in quantitative studies (Denzin \& Lincoln, 2000, p. 21). Credibility was addressed through member checks, follow-up interviews via telephone, and referential adequacy (e.g., the storage and accessibility of cassette tapes from the interviews, full transcripts, and confidential documents). An informant team consisting of at least two participants from each institution was established for member checks. This team, representing over $25 \%$ of the sample, read and provided feedback on our written interpretations of their collective experiences.

Additionally, feedback from six peer debriefers who are experienced qualitative researchers and are familiar with African American men's issues was solicited to ensure credibility. Debriefers were given raw transcripts, as well as the individual textural and structural descriptions written for the study participants. Debriefers engaged the lead 
researcher in a series of ongoing discussions regarding the tentative meanings made of the participants' experiences throughout the data analysis phase of the study. Transferability is ensured by the earlier description of sites from which data were collected. Findings from this study will likely transfer agreeably to other large predominantly White public research universities. Finally, dependability and confirmability were ensured through audits conducted by members of the aforementioned peer debriefing team, a diverse team of four senior faculty colleagues, and one additional qualitative research methodologist.

\section{Limitations}

Despite efforts to ensure trustworthiness, three shortcomings are readily apparent. First, given the limited number of administrators who were asked to nominate African American male student leaders on each campus, selection bias likely prohibited certain students from being nominated to participate in the study. Although most administrators conferred with other colleagues before offering a final list of nominees, in many cases they identified student leaders with whom they had worked closely and were most familiar. There very well could have been additional African American male student leaders on the six campuses who were overlooked because they had not interacted or formed relationships with the nominators.

A second major shortcoming pertains to the limited transferability of the findings from this study. African American male students with similar profiles at single-sex institutions, historically Black universities, small liberal arts colleges, and other institutional types might report experiences that differ from those of the 32 participants who attended the six large PWIs in the present study. Finally, unlike previous studies of Black identity development among African American college students, no inventory or instrument was used in this study to quantitatively ascertain the participants' racial identity attitudes. Although the focus in the present study is primarily on identity expression and development vis-à-vis student organizations, no systematic approach was employed to place the participants at various stages in Cross's (1995) model. Despite this, several qualitative indicators of the students' racial identity statuses are offered through verbatim quotes in the next section.

\section{FINDINGS}

From the data analysis emerged two sets of findings related to the development and expression of the participants' Black identities within the context of student organizations. One pertains to the impetus for their leadership and engagement in both predominantly Black and mainstream/majority White student organizations. The other focuses on the ways in which student organizations afforded the participants opportunities to develop valued cross-cultural communication skills, enabled them to learn from others who were racially different, and fostered among them care and advocacy for other disadvantaged populations. Findings in these two areas are reported in this section and connections to previous research on Black identity development are discussed thereafter.

\section{For the Advancement of the African American Community}

Although some held membership in mainstream campus organizations, the participants' leadership and engagement were overwhelmingly situated in predominantly Black and minority student organizations. Regardless of the organizations he chose or the positions he held, each student leader articulated a commitment to uplifting the African American community (both on campus and broadly defined) and 
devoted himself to dispelling stereotypes, breaking down barriers, and opening new doors for other African American students on his campus. Regarding their impetus for involvement, here are some of the reflections offered in the interviews:

Recognizing the need for African Americans to be on a level playing field with other races and for African American students to know about certain things that they otherwise wouldn't have been exposed to has prompted me to become active on campus. (Daniel, University of Michigan)

I tried to think of ways that I could benefit my community and make it easier for other African American students to graduate. If you look at the retention rates for African Americans on this campus, especially the guys, you'd be like, "Wow this is really messed up!" That is why I got involved. (Jamein, Michigan State University)

I took an African American Studies class my first year here . . . it brought light to the statistics in our community and how the African American community is hurting right now. I felt that I needed to do something, starting here on campus as a student leader, to help my brothers and sisters, just like the people who had come before me had done things that got me introduced to certain opportunities. I committed myself to helping other African Americans gain access to more of those opportunities. (Keely, University of Illinois)

I wanted to join many different types of organizations so that I could develop skills and get programming ideas that I could transfer back to the Black student organizations, to make the Black organizations stronger and more effective. I've been especially successful in doing this for my fraternity and Black Student Union. (Marshawn, Indiana University)
In his own way, each student leader articulated a commitment to racial uplift, which was the prevailing driver of his affiliation with various clubs and organizations.

The participants spoke in detail about doing their part in responding to the issues that African American and other minority students faced on campus. Many were cognizant of the low retention and graduation rates among African American students and responded through programs and initiatives in their student organizations. Two participants described the 4.0 Club they co-founded on the University of Illinois campus. "We registered the student organization so we could have study halls for African American students to study together and support each other academically because the African American students' GPAs are considerably lower than the campus average." Members of the $4.0 \mathrm{Club}$ reserved a study table for members at the campus library, participated in occasional study sessions from 8:00 p.m. to 6:00 a.m., and provided recognition incentives for those members who actually achieved 4.0 GPAs at the end of each semester. This was just one way that these two student leaders attempted to help address the academic underachievement issues that plagued their same-race peers. Other students described a variety of academic and non-academic initiatives in which they had been involved to specifically help respond to the retention crisis among the African American male undergraduates on their campuses.

An interesting observation was made regarding the student organizations the participants selected. Those who chose to be exclusively involved in predominantly Black organizations did so because they were primarily concerned with being affiliated with groups that responded directly to African American students' needs and concerns. In explaining his selection of student organizations 
and campus activities at Michigan State, Alric shared:

I am mostly involved in Black and minority initiatives because they provide a platform for me to plan programs for the most disadvantaged students here at the university_-students who look like me. I see the personal value in getting involved in some mainstream activities, but I feel as though I could have a greater impact on students of color through the Black Student Alliance, the Black caucuses, the Racial/Ethnic Aide Program and my other organizations. It's not so much about me-it's more about involving myself in things that will advance our race.

Those who were more involved in the predominantly White and mainstream student organizations mostly chose to do so because they saw an inadequate representation of African American students in those clubs and wanted to be among the first to diversify the groups. They also knew the mainstream student organizations had greater resources and funds for programming that could be accessed on behalf of Black and minority student groups. Several participants noted that they joined those groups to get minority initiatives funded; to advocate bringing African American speakers, musicians, and entertainers to campus; and to promote collaboration between those organizations and the Black and minority student groups with which they were also affiliated. One student leader offered this example: "I joined Union Board because they bring all the concerts to campus. I noticed that they kept bringing nothing but White artists. Because of me, Union Board and Black Student Union co-sponsored the first hip-hop concert we've ever had." Although they sometimes chose demographically different organizations, the participants shared the same goal: advancing the African American student communities on their campuses.
The student leaders often leveraged their influence and reputations to gain access to key administrators on their campuses. An Ohio State student shared:

I have the ear of the Vice President for Student Affairs. I often go to him to ask for money for different initiatives for Black students and he listens because he sees me as a notable ambassador of the Black community.

Student organizations offered venues through which the voices of African American students could be shared and the needs of racial/ethnic minority students could be advocated. Keely, the student representative on the Board of Trustees at the University of Illinois, remarked:

When I sit around a table in a meeting with the Board of Trustees or a student leadership group, it's a very White room. It is my hope that $\mathrm{I}$, as well as some of the other African American men that you're interviewing here, have gotten into the minds of administrators that this campus needs to be a lot more diverse. If we weren't seated around those tables, who'd advocate for our needs?

Keely's comments are consistent with reflections offered by other participants on the six campuses.

The student leaders were compelled to get involved in order to have their voices and the voices of the African American community heard. "Not too many African American students are involved at Ohio State. I just wanted to get myself out there and be a representative, to represent the African American voice, which otherwise wouldn't be heard by these White administrators," Chaz noted. Many participants saw the value of having minority representation on various committees that set policies for the campuses. They realized that racial/ethnic minority students had been previously disadvantaged 
because they lacked student participation in important institutional decision-making processes. Christopher, Vice President of the Student Association at Indiana University, commented:

Most Black student organizations are struggling financially here at IU because they don't have anyone seated at the table when resources are allocated to clubs. I've been able to do that through IUSA, which gives out thousands of dollars each year. It is the majority White groups that know about these funding opportunities - not so much for the Black groups. Since I have become the VP of IUSA, I have made sure that Black Student Union, Kappa Alpha Psi [a historically Black fraternity], and other Black groups have gotten a portion of those funds. I've personally gone to some Black student groups' meetings to tell them about resources that are available to finance their programming. If I weren't the VP, most Black groups wouldn't know this information.

The participants sometimes volunteered to provide an African American perspective in different student organizations and on various university committees; other times they were involuntarily forced into those roles. Many referred to themselves as the "token Black male." For instance, David, a student at Purdue, shared the following story:

I've been appointed to the Student Leadership Board, which is a committee that consists of all the presidents or representatives of the elite student organizations on campus. ... [another student] and I were asked to be on that Board because, I hate to say it, but we're the token African American males, which I have no problem accepting. We walked in the first meeting and we were both like, "Okay, now we know why we were invited." Nonetheless, it's an honor to have been selected. More importantly, it's even more of an honor to provide an
African American voice that was missing.

Interestingly, blatant tokenism did not seem to bother the participants, as Cullen asked, "If not me, who?" They accepted responsibility for speaking on behalf of African Americans and other racial/ethnic minority persons on a variety of platforms. At some point, they noticed there was a shortage of African American student leaders taking a stance on major campus issues and voicing the concerns of the community to the president and other administrators - they endeavored to provide that voice.

\section{Cross-Cultural Engagement and Advocacy for Oppressed People}

Cross-cultural communication was the most frequently cited skill mentioned throughout the interviews. The participants reported that they had successfully learned how to work with people who were different in terms of race, ethnicity, nationality, sexual orientation, ability, socioeconomic status, and religion. They clearly understood that in order to be successful they needed to forge relationships with people from different backgrounds. The student leaders also told how they were genuinely interested in meeting peers who were different and could offer different points of view. Mike spoke extensively about the positive relationships he formed with Jewish, Asian, and international students from India at Ohio State and how he learned that "everything in society is not just Black and White." The participants were cognizant of the fact that their college campuses were microcosms of the larger society. They knew, for example, that most top-ranked MBA programs enrolled several international students; they remembered from their summer internships that companies tended to be multicultural and globally focused; and they were aware that some of their 
non-African American peers from college would go on to become senators, business executives, and leaders in the future.

Working with diverse populations in campus organizations enabled them to learn about and appreciate the differences that people bring to various settings. In return, they were able to teach diverse others about their unique backgrounds, life histories, and Black culture. "Whenever I get the opportunity, I have conversations with White people or Asian people if I can turn it into a learning experience for them," Brian noted. Although they all mentioned working with various cultures, significant emphasis was often placed upon "learning to deal with White people." Many participants considered this skill a gift that many of their African American peers did not have, but something that was essential for future success. "So many African Americans are miserable in college and in their jobs because they don't know how to deal with White people ... they really aren't that hard to work with once you figure them out," one student commented. An interesting observation was made with regard to the participants' language when discussing their cross-cultural experiences. The students usually chose the phrase "interact with" when they spoke more generally about their exchanges with peers from different cultural and racial/ethnic minority backgrounds, but used "deal with" when referring specifically to their interactions with White people. This semantic difference is noteworthy, as it indicates variable levels of comfort and authenticity in cross-racial interactions and relationships.

Nearly all of the participants spoke of their African American peers' refusal to interact with and learn about different cultures. Landon offered the following perspective:

Most of the Black students at Purdue are associated with themselves and that's where they draw the line. A lot of times, people will come from Black communities and that's where they stay. They come to this White school, they find the Black community, and that's where they stay because they're comfortable.

Intentional self-segregation, the participants believed, was fueled by issues of discomfort, previous negative experiences with White persons and people from other racial/ethnic backgrounds, and sometimes just blatant racism. A junior at Michigan State reflected on how disappointed he was with the racist attitudes displayed by his African American peers toward other cultures.

I love Black people, but I hate the closemindedness and prejudices many of us have toward others and the stereotypes we generalize about other students, especially because we don't like for someone to make generalizations or advance stereotypes about us.

Student organization membership afforded the participants opportunities to interact with peers outside of the African American community. Because of this, they acquired the skill of working cooperatively with diverse others. Edwin, Vice President of the Pre-Med Association at the University of Michigan, recognized the long-term benefits of his crosscultural interactions in college. He realized, for instance, that most hospitals are multicultural and serve diverse populations. "Student groups have introduced me to people of other cultures, and have really prepared me to go into the world of medicine where I'll treat and constantly interact with a lot of patients from different racial and cultural backgrounds."

Like other student leaders in the study, Edwin also acquired a heightened awareness of the effects of oppression on other marginalized groups at his institution. Specifically, he was an organizer for Victory Over Violence Week at the University of Michigan, which 
focused on eradicating rape and other forms of assault against women. Edwin offered this explanation for his involvement in a predominantly female initiative:

As a Black man, I understand what it is like to be victimized and assaulted. Because of this, I have joined others in helping prevent the victimization of women on this campus. I am obviously not a woman, but I have firsthand experience with oppression and I want to stop it, not just for African Americans, but for women as well. Quite honestly, I have learned a lot about gender issues and how to collaborate with women to end oppression.

Other participants described their interactions with students from marginalized groups. "Before I came to college, I was raised to think that homosexuals were going to hell. Last semester, I marched in a rally for their rights because I understand how it feels to be overlooked on this campus," a University of Illinois student commented. Similarly, although most of his involvement was situated in Black student organizations, Bryant attributed his sensitivity for the needs and concerns of gay and lesbian students, as well as students with disabilities to his service as a Resident Assistant. Amondo remarked, "I would like to end oppression against all groups here at Michigan State, not just Blacks.”

\section{DISCUSSION}

Internalization, the final stage of Cross's (1995) model of Black identity development, signifies an inner comfort with one's Blackness, the ability to form alliances with other members outside of one's racial group (including White people), and a commitment to enacting change that will result in social justice for African Americans and other oppressed groups. Leadership and engagement in student organizations enabled the participants in the present study to embody many of these characteristics. Specifically, the juxtaposition of their dominant participation in Black student organizations with their willingness to engage in other groups that afforded opportunities for crosscultural learning and advocacy on behalf of gay and lesbian students, women, and other socially marginalized groups on their campuses is consistent with attitudes and behaviors displayed by those at the Internalization stage in Cross's model.

Harper's (1975) finding that African American men's engagement is primarily situated in Black student organizations also held true in the present study, although many participants were also involved to varying degrees in mainstream and predominantly White groups. Inconsistent with Mitchell and Dell's (1992) claims, there was no evidence here that those who were more engaged in Black and minority student organizations expressed their Black identities with any more intensity than those who were involved in a wider range of student organizations. Perhaps this would have been different were any of the participants engaged exclusively in mainstream and predominantly White organizationsnone were. However, their recognition of and firsthand experiences with social disadvantage did compel many participants to pursue membership in some mainstream organizations. This behavior coincides with McEwen et al.'s (1990) Developing Social Responsibility dimension of Black identity development. Moreover, the dominance of their affiliation with Black student organizations, which presumably requires some level of collective action and collaboration with other African American students, corresponds agreeably with the Ujima principle in Robinson and HowardHamilton's (1994) Africentric Resistance Modality Model.

As previously mentioned, the nominating administrators indicated that these 32 under- 
graduates were the most actively engaged African American male student leaders on the six campuses. Like the highly involved participants in Taylor and Howard-Hamilton's (1995) study, student leaders in the present study overwhelmingly displayed Internalization attitudes. The difference here is that the behavioral manifestations of such attitudes through student organization membership were also explored. Put simply, leadership and engagement for social justice and racial uplift were the primary ways through which Internalization attitudes were expressed behaviorally. Using Cokley's (1999) term, participants were "racially aware," as evidenced by the purpose with which they approached their work in structured venues outside of the classroom. Clubs and organizations-predominantly Black and minority, as well as mainstream and majority White_offered platforms through which the African American men in this study could champion Black causes; advocate for support and resources to meet the needs of racial/ethnic minority students; and offer a voice that was often missing when decisions were being made regarding campus policies, the allocation of resources, and the selection of speakers and entertainers that student organizations brought to campus.

It is important to note that the 32 participants were able to maintain their Black identities within the context of predominantly White student organizations. Cross (1995) suggested that those at the Internalization stage are able to selectively subscribe to both Black and White cultures without forfeiting one for the other. That was the case here, as the African American male student leaders adapted to mainstream student organizations and established relationships with White peers through those groups while simultaneously advancing their own minority-focused agendas and Black student interests. Regardless of the racial makeup of their out-of-class involvement venues, improving the status and conditions of African American students on their campuses was the primary impetus for the participants' leadership and engagement.

Findings clearly indicate that student organization membership helped enhance the development of the participants' Black identities. Characteristic of those at the final stage in Cross's (1995) model of Black identity development is the ability to interact comfortably with White people while maintaining a sense of one's own Blackness and developing care for other marginalized groups. Regarding the former, clubs, organizations, and activities enabled the student leaders to develop sharper cross-cultural communication skills and recognize the value of interacting across cultural differences. Working on committees and programmatic initiatives cultivated within the participants the skill of "dealing with" White people, which is discussed further in the implications section. Reportedly, learning this while concurrently maintaining and exerting one's authentic sense of Blackness in student organizations was a useful exercise. This is particularly noteworthy because the participants indicated their same-race peers typically avoided and were generally not engaged in structured efforts that facilitated opportunities for cross-cultural learning and skill acquisition in this regard.

Vandiver et al.'s (2001) addition of the Multiculturalist Inclusive cluster to the Internalization stage of Cross's (1995) model pertains to a person's ability to bridge differences and craft action-oriented responses to multiple forms of oppression. Participants in the present study were able to go beyond their cultural comfort zones by interacting with diverse populations of peers within their organizations. Furthermore, they were compelled to commit themselves to (but also move beyond) African American and racial/ethnic minority-focused initiatives and become agents 
of social change for other oppressed and disadvantaged groups on their campuses. Student organizations offered a platform through which their familiarity with the needs and challenges of others, care for marginalized populations, and pragmatic solutions for eradicating social injustices could be developed and expressed.

\section{IMPLICATIONS AND CONCLUSION}

As mentioned previously, although factors leading to premature departures from college are numerous and not easily credited to a narrow set of variables and conditions (Braxton, 2000; Tinto, 2005), scholars have attributed a portion of college student attrition to identity development challenges among students in general (Evans et al., 1998) and African American male undergraduates in particular (Cuyjet, 2006; Harper, 2004). Given that only $32.4 \%$ of African American men who start college actually persist through baccalaureate degree attainment (Harper, 2006a; NCES, 2005), it seems appropriate to recommend that educators invest energies into introducing these students to venues in which their identities can be developed and expressed. Student organizations, both predominantly Black and mainstream, should be marketed as outlets for African American men to learn more about themselves and others, contribute to programmatic and advocacy efforts that will improve their own quality of life as well as that of marginalized others on campus, and afford them opportunities to develop a set of crosscultural communication skills that will prove useful in their post-college endeavors.

Although the participants in this study expressed no dissatisfaction with assuming responsibility for representing the Black race in student organizations, advisors and administrators should be careful not to tokenize those who choose to become members and leaders.
Expecting them to speak on behalf of all African Americans and racial/ethnic minority students is inappropriate and will likely decrease some students' willingness to continually consider mainstream student organizations as suitable outlets for engagement. Similarly, although Cross (1971, 1991, 1995) portrays Internalization as the optimal level of racial identity functioning, educators should be cognizant of the varied backgrounds from which African American men come and therefore not assume that every student finds engagement in social work on behalf of disenfranchised populations on his campus appealing. Instead, faculty and student affairs educators should engage African American men in conversations about the ways in which they define their Blackness, the racial realities of their college experiences, and their expectations of the institution's response to racism and social injustice. Based on where students are developmentally, organizations and activities that will enable them to further explore their identities and respond to the social issues they deem important should be introduced.

Those who work with mainstream student organizations in an advisory capacity should engage White student stakeholders in a process of creating spaces for African American men and other underrepresented students to offer culturally based ideas, programming, and advocacy. According to Harper (2006c), several student organizations espouse commitments to diversity and multiculturalism in their mission statements, but few White student leaders are actually held accountable for enacting such values. The participants in the present study were afforded the space to engage in social work and collaborative partnerships to address needs and issues that concerned African Americans and other populations. Ways in which racial/ethnic minority students negotiate access and factors that compel White students to provide this space in mainstream 
clubs and organizations warrants further investigation.

Many participants mentioned learning to deal with White people as a self-reported gain associated with their engagement in mainstream student organizations. Although the acquisition and perceived transferability of this skill is noteworthy, advisors should pay particular attention to facilitating opportunities for more meaningful cross-cultural interactions that result in learning, sharing, and mutually rewarding collaboration across races, instead of simply dealing with peers who are racially different. The long-term effects and transferability of what the African American male student leaders deemed as learning to "deal with" White people is also worthy of future research.

Finally, the value of and continued need for predominantly Black and minority student organizations should not be overlooked. These organizations served as the primary venues for African American male student engagement on the six campuses in this study. Without them, some of the participants may not have found a place for the expression and development of their Black identities. Though many found opportunities for racial uplift and the representation of Black interests in mainstream and majority White student organizations, the predominantly Black groups offered an alternative platform through which to address Black issues, connect with other African American students, and initiate dialogue and programming without feelings of tokenism. Among African American male first-year students and those who are not involved, it is highly likely that most will first consider Black student organizations as initial venues for engagement before branching out to mainstream and majority White groups (Harper, 2006c). Thus, educators and administrators who are interested in increasing engagement and enhancing outcomes (including identity development) among African American male undergraduates must provide financial, advisory, and other forms of support to predominantly Black and minority student organizations. The participants in this study reflected positively on the role of these groups and mainstream student organizations in the development and expression of their Black identities.

Correspondence concerning this article should be addressed to Shaun R. Harper, Center for the Study of Higher Education, The Pennsylvania State University, 400 Rackley Building, University Park, PA, 16802; sharper@psu.edu

\section{REFERENCES}

Arminio, J. L., Carter, S., Jones, S. E., Kruger, K., Lucas, N., Washington, J., et al. (2000). Leadership experiences of students of color. NASPA Journal, 37, 496-510.

Braxton, J. M. (2000). Reinvigorating theory and research on the departure puzzle. In J. M. Braxton (Ed.), Reworking the student departure puzzle (pp. 257-274). Nashville, TN: Vanderbilt University Press.

Brown, O. G. (1994). Debunking the myth: Stories of African American university students. Bloomington, IN: Phi Delta Kappa.

Carnegie Foundation for the Advancement of Teaching. (2000). The Carnegie classification of institutions of higher education. Stanford, CA: Author.

Cokley, K. O. (1999). Reconceptualizing the impact of college racial composition on African American students' racial identity. Journal of College Student Development, 40, 235-246.

Cokley, K. O. (2001). Gender differences among African American students in the impact of racial identity on academic psychosocial development. Journal of College Student Development, 42, 480-487.

Cross, W. E., Jr. (1971). Toward a psychology of Black liberation: The Negro-to-Black conversion experience. Black World, 20, 13-27.

Cross, W. E., Jr. (1991). Shades of black. Philadelphia, PA: Temple University Press.

Cross, W. E., Jr. (1995). The psychology of Nigrescence: Revising the Cross model. In J. G. Ponterotto, J. M. Casas, L. A. Suzuki, \& C. M. Alexander (Eds.), Handbook of multicultural counseling (pp. 93-122). Thousand Oaks, CA: Sage.

Cross, W. E., Jr., \& Vandiver, B. J. (2001). Nigrescence theory and measurement: Introducing the Cross Racial Identity Scale (CRIS). In J. G. Ponterotto, J. M. Casas, L. A. Suzuki, \& C. M. Alexander (Eds.), Handbook of multicultural counseling (2nd ed., pp. 371-393). Thousand Oaks, CA: Sage. 
Cuyjet, M. J. (2006). African American college men: Twentyfirst century issues and concerns. In M. J. Cuyjet (Ed.), African American men in college (pp. 3-23). San Francisco: Jossey-Bass.

Denzin, N., \& Lincoln, Y. (2000). Introduction: The discipline and practice of qualitative research. In N. Denzin \& Y. Lincoln (Eds.), Handbook of qualitative research (2nd ed., pp. 1-28). Thousand Oaks, CA: Sage.

Evans, N. J., Forney, D. S., \& Guido-DiBrito, F. (1998). Student development in college: Theory, research, and practice. San Francisco: Jossey-Bass.

Flowers, L. A. (2004). Examining the effects of student involvement on African American college student development. Journal of College Student Development, 45 , 633-654.

Fries-Britt, S. L. (1998). Moving beyond Black achiever isolation: Experiences of gifted Black collegians. The Journal of Higher Education, 69, 556-576.

Fries-Britt, S. L. (2000). Identity development of high-ability Black collegians. In M. B. Baxter Magolda (Ed.), Teaching to promote intellectual and personal maturity: Incorporating students' worldviews and identities into the learning process. New Directions for Teaching and Learning (No. 82, pp. 55-65). San Francisco: Jossey-Bass.

Fries-Britt, S. L. (2002). High-achieving Black collegians. About Campus, 7(3), 2-8.

Fries-Britt, S. L., \& Turner, B. (2001). Facing stereotypes: A case study of Black students on a White campus. Journal of College Student Development, 42, 420-429.

Guiffrida, D. A. (2003). African American student organizations as agents of social integration. Journal of College Student Development, 44, 304-319.

Harper, F. D. (1975). Black students, White campuses. Washington, DC: APGA Press.

Harper, S. R. (2004). The measure of a man: Conceptualizations of masculinity among high-achieving African American male college students. Berkeley Journal of Sociology, 48, 89-107.

Harper, S. R. (2005). Leading the way: Inside the experiences of high-achieving African American male students. About Campus, 10(1), 8-15.

Harper, S. R. (2006a). Black male students at public universities in the U.S.: Status, trends and implications for policy and practice. Washington, DC: Joint Center for Political and Economic Studies.

Harper, S. R. (2006b). Peer support for African American male college achievement: Beyond internalized racism and the burden of "acting White." Journal of Men's Studies, 14, 337-358.

Harper, S. R. (2006c). Enhancing African American male student outcomes through leadership and active involvement. In M. J. Cuyjet (Ed.), African American men in college (pp. 68-94). San Francisco: Jossey-Bass.

Harper, S. R., Byars, L. F., \& Jelke, T. B. (2005). How membership affects college adjustment and African American undergraduate student outcomes. In T. L. Brown, G. S. Parks, \& C. M. Phillips (Eds.), African American fraternities and sororities: The legacy and the vision (pp. 393-416). Lexington: University Press of Kentucky.
Helms, J. E. (Ed.). (1990). Black and White racial identity: Theory, research, and practice. Westport, CT: Greenwood Press.

Holstein, J. A., \& Gubrium, J. F. (1995). The active interview. Qualitative research method series, No. 37. Thousand Oaks, CA: Sage.

Howard-Hamilton, M. F. (1997). Theory to practice: Applying developmental theories relevant to African American men. In M. J. Cuyjet (Ed.), Helping African American men succeed in college. New Directions for Student Services (No. 80, pp. 17-30). San Francisco: Jossey-Bass.

Howard-Hamilton, M. F. (2000). Creating a culturally responsive learning environment for African American students. In M. B. Baxter Magolda (Ed.), Teaching to promote intellectual and personal maturity: Incorporating students' worldviews and identities into the learning process. New Directions for Teaching and Learning (No. 82, pp. 55-65). San Francisco: Jossey-Bass.

King, P. M., \& Howard-Hamilton, M. F. (2000). Using student development theory to inform institutional research. In J. W. Pickering \& G. R. Hanson (Eds.), Collaboration between student affairs and institutional researchers to improve institutional effectiveness. New Directions for Institutional Research (No. 108, pp. 19-36). San Francisco: Jossey-Bass.

Lincoln, Y., \& Guba, E. G. (1986). But is it rigorous? Trustworthiness and authenticity in naturalistic observation. In D. Williams (Ed.), Naturalistic evaluation. New Directions for Program Evaluation (No. 30, pp. 73-84). San Francisco: Jossey-Bass.

McEwen, M. K., Roper, L. D., Bryant, D. R., \& Langa, M. J. (1990). Incorporating the development of African-American students into psychosocial theories of student development. Journal of College Student Development, 31, 429-436.

Miles, M. B., \& Huberman, A. M. (1994). Qualitative data analysis: An expanded sourcebook (2nd ed.). Thousand Oaks, CA: Sage.

Mitchell, S. L., \& Dell, D. M. (1992). The relationship between Black students' racial identity attitude and participation in campus organizations. Journal of College Student Development, 33, 39-43.

Moustakas, C. (1994). Phenomenological research methods. Thousand Oaks, CA: Sage.

National Center for Education Statistics. (2005). Integrated Postsecondary Education Data System Washington, DC: U.S. Department of Education, Institute of Education Sciences.

Polkinghorne, D. E. (1989). Phenomenological research methods. In R. S. Valle \& S. Halling (Eds.), Existentialphenomenological perspectives in psychology (pp. 41-60). New York: Plenum.

Pope, R. L. (1998). The relationship between psychosocial development and racial identity of Black college students. Journal of College Student Development, 39, 273-282.

Robinson, T. L., \& Howard-Hamilton, M. F. (1994). An Africentric paradigm: Foundations for a healthy self-image and healthy interpersonal relationships. Journal of Mental Health Counseling, 16, 327-339.

Sedlacek, W. E. (1987). Black students on White campuses: 20 years of research. Journal of College Student Personnel, 28, 484-495. 
Sutton, E. M., \& Terrell, M. C. (1997). Identifying and developing leadership opportunities for African American men. In M. J. Cuyjet (Ed.), Helping African American men succeed in college. New Directions for Student Services (No. 80, pp. 55-64). San Francisco: Jossey-Bass.

Taylor, C. M., \& Howard-Hamilton, M. F. (1995). Student involvement and racial identity attitudes among African American males. Journal of College Student Development, 36, 330-336.

Thompson, C. E., \& Carter, R. T. (1997). An overview and elaboration of Helms' racial identity development theory. In C. E. Thompson \& R. T. Carter (Eds.), Racial identity theory: Applications to individual, group, and organizational interventions (pp. 15-32). Mahwah, NJ: Erlbaum.

Torres, V., Howard-Hamilton, M. F., \& Cooper, D. L. (2003). Identity development of diverse populations: Implications for teaching and administration in higher education. ASHE-ERIC Higher Education Report (Vol. 29, No. 6). San Francisco: Jossey-Bass.
Tinto, V. (2005). Moving from theory to action. In A. Seidman (Ed.), College student retention: Formula for student success (pp. 317-333). Washington, DC: ACE and Praeger.

Vandiver, B. J., Fhagen-Smith, P. E., Cokley, K. O., Cross, W. E., \& Worrell, F. C. (2001). Cross' Nigrescence Model: From theory to scale to theory. Journal of Multicultural Counseling and Development, 29, 174-200.

Vandiver, B. J., Cross, W. E., Jr., Worrell, F. C., \& FhagenSmith, P. E. (2002). Validating the Cross Racial Identity Scale. Journal of Counseling Psychology, 49, 71-85.

White, L. S. (1998). "Am I Black enuf fo ya?” Black student diversity, issues of identity and community. In K. Freeman (Ed.), African American culture and heritage in higher education research and practice (pp. 91-119). Westport, CT: Praeger.

Worrell, F. C., Cross, W. E., Jr., Vandiver, B. J. (2001). Nigrescence theory: Current status and challenges for the future. Journal of Multicultural Counseling and Development, 29, 201-213. 